\title{
Content Marketing Through Online Media For Development of A Business
}

\author{
I Yanuarti ${ }^{1}, \mathrm{~N}$ Karniawati ${ }^{2}$ \\ \{yanuarti.irma@email.mahasiswa.unikom.ac.id ${ }^{1}$, nia.karniawati@email.unikom.ac.id ${ }^{2}$ \}
}

Department of Communication Science, Universitas Komputer Indonesia, Indonesia ${ }^{1}$, Department of Government Science, Universitas Komputer Indonesia, Indonesia ${ }^{2}$

\begin{abstract}
The purpose of this research is to find out how important content marketing is done through online media for the development of a business. The method used in this research is descriptive method, to present a complete overview of the situation related to several variable situations that are examined. The result of this research is that attractive content marketing has an important role in the development of business because attractive content marketing can help increase customers' trust in the products or services offered. Through content marketing, a business can convey the values applied to its brand as well as various information related to the product or service offered. From there the community will be aware of the existence of a brand and recognize its character and value so that eventually they will put trust in the product or service offered and will build linkages between brands of business and customers. Content marketing that is made will add the value of a product and the purpose of the product so that it can be understood and consumers are more interested. From the result of this research, it can be concluded that attractive content marketing is very important to increase consumer's trust.
\end{abstract}

Keyword: Marketing, Social Media, Business

\section{Introduction}

Marketing is one of the most important things in business factors. At this time marketing is done a lot through social media and on the internet. Marketing requires a storyline or a strong content so that it can be delivered properly. The use of technology information in marketing can be seen such as in online media which includes blogs and social media (Facebook, Instagram, WhatsApp, and Telegram). According to Soegoto, marketing is the process of planning and implementing conception, pricing, promotion, and distribution of ideas, goods and services to create exchanges in order to satisfy the needs of customers and companies at once. He further explained that the basic principles of marketing are creating value for customers, competitive advantage, and marketing focus. The marketing goal is not to get customers, but to improve the competitive situation. In this context, an entrepreneur must be able to produce goods and services with better quality, lower prices, and faster delivery than competitors. Therefore, the right marketing strategy is needed to carry out this marketing activity [1]. Based on the understanding of Slater, marketing strategy is a set of integrated decisions and actions by which a business expects to achieve the marketing objectives and meet the value requirements of its customers [2]. Furthermore, Varadarajan stated that marketing strategy is conceptualized as an 
organization's crucial choices concerning products, markets, marketing activities and marketing resources in the creation, communication and/or delivery of products that offer value to customers in exchanges with the organization [3]. Limandono et al said that the current development of the digital era has affected the world, where everyone competes to show who is the best, where at this time in the context of good promotion, it no longer uses advertising on material that is better than content [4]. The understanding of content marketing according to Ahmad N. S et al is the active role of consumer participation for sharing and participates in media space that becomes their interest. So, it is clear that the main point of creating the content marketing is to distribute the value and consistency of the content itself to the target audience to drive the profitable customer action [5]. In the online era, as content marketing now usually uses online media, online media is one type of communication media that can only be used when there is access to the internet. Marketing through online media can be very effective if done in an appropriate way, in the sense that it can attract potential customers because they feel there is value offered as a solution to the problems faced. Therefore we need mature content marketing to be able to convey important messages around the products or services offered by a business.

Holliman, et al in his research found that content marketing is an inbound marketing technique, affected through web page, social media, and value-add content, and is perceived to be a useful tool for achieving and sustaining trusted brand status [6]. Baltes in his research stated that it is important to know that content marketing has benefits in terms of retaining reader attention and improving brand loyalty. The idea of sharing content as a means of persuading decision-making has driven content marketers to make their once-proprietary informational assets available to selected audiences. Alternatively, many content marketers choose to create new information and share it via any and all media [7]. Furthermore, research conducted by Harad $\mathrm{K}$ found that content marketing is an art and science that regularly shares valuable information with aligned target audiences so that it can strengthen a brand. Content marketing is promoting without selling, giving, and receiving approaches without generating interest, attracting prospects, and building trust. Content marketing is a belief to share opinions and knowledge, which will generate income in the form of actions from the audience, namely being loyal customers [8]. While the research conducted by Grubor et al found that today, consumers seek from companies and brands high level of consistency in terms of basic values, concepts, visions, and focus, they are also constantly looking for the introduction of novelty, originality, modernity, and creativity. So, from the standpoint of a company, content marketing is a new form of attracting the attention of consumers but in a way that is preferred from their perspective and is seen as the powerful instrument for creating brand equity. For consumers, it is valuable content that is seen as something new, educational, entertaining, enlightening, and useful, that attracts attention and is aligned with the consumer's state of mind, lifestyle, value system, interests, and needs. The main goal of content marketing is to achieve "content-ment" for both consumers and business [9]. Research conducted by Halvorson found that in general, content marketing is a marketing technique which involves creating and spreading contents valuable from the point of view of recipients of the content, aimed at drawing attention and thus engaging a community gathered around a particular target group. Content are what users want to read, learn about, watch, or experience. From the perspective of business, content is important information presented on a website, in an application or by means of other available channels of digital presentation, which have the mission of communicating [10].

The purpose of this research is to find out how important content marketing is done through online media for the development of a business. The method used in this research is descriptive method, to present a complete overview of the situation related to several variable situations 
that are examined. The result of this research shows that it can be concluded that attractive content marketing is very important to increase consumers trust.

\section{Methods}

The method used is descriptive analysis. Descriptive method is used to find out the variables related to content marketing, online media, and business. Data collection techniques that are used are the study of literature and observation. This discussion is more used in the explanation of the content of a product that is displayed in the form of a website with some content displayed in the discussion so that it can be figured the type of content that is appropriate in this study.

\section{Results and Discussion}

In the world of technology, content marketing refers to online content such as blogs, press releases, social media posts, bulletins, videos, and also images that are specifically designed to improve relationships with consumers. The content is the result of thinking and contains information that can provide added value to the reader or consumer by increasing the exposure of the company. However, content marketing is not just an ordinary post but is specifically designed to interact, relate, and give the impression to consumers to know more about the products or services offered. This is also reinforced by research called "A new development in online marketing: Introducing digital inbound marketing" that talks about online business development [11].

Marketing content through online media, especially through the use of websites and social media such as Instagram, is an effective way for a business to market itself. In addition to creating brand awareness, content marketing can also increase customer trust in a product or service from a business and to be more widely known by the public. In order for the content to be valuable and meaningful, the content must be designed in such a way as to suit the desired target audience. Content marketing must also be updated regularly. Through content marketing, a business can convey the values that it wants to impart or share information regarding the products or services offered. For example, a business that offers watch products uses content marketing as a marketing strategy for its products. The content marketing can be seen both from the official website of the watch product business and from Instagram.

On the website, this business uses several types of content at once as its content marketing. The forms of the content contained on this website include video, storytelling, FAQ, media coverage, product information, and product review.

Video is a very interesting form of content that can be easily shared. But content in the form of video requires a greater investment of time and resources than written content, but with increasing popularity of visual marketing, video content can attract the attention of visitors on the website.

Content in the form of storytelling will refine the marketing process. Content in the form of storytelling will make an emotional appeal, and if the audience is emotionally attracted then it will be easier to attract their attention (see Figure 1). 


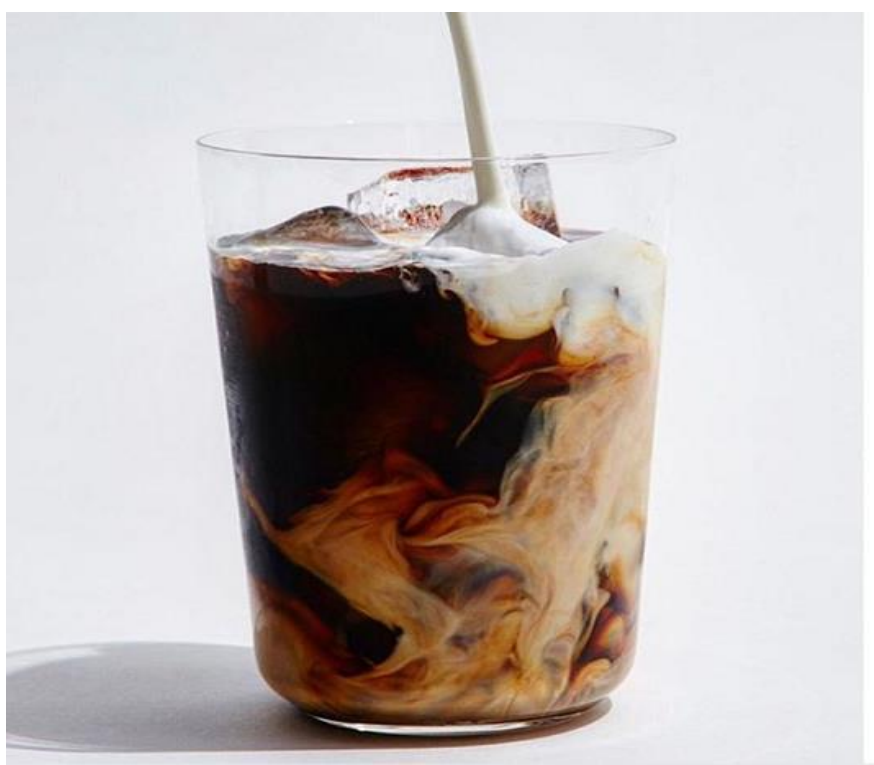

mouthfoods Fun fact: DST ชิ was first proposed by Benjamin Franklin in his 1784 essay "An Economical Project for Diminishing the Cost of Light." He suggested people get up earlier to make better use of available $\{$ and save the use of... candle wax. Thanks, Ben (2)Today we're powering through with all things $\theta$. like Grady's Cold Brew and @eatyour.coffe java-spiked energy bars $\&$ Hit the link in bio to check out our faves $\{$, @gradyscoldbrew mouthfoods .

\#EEEEEATS \#indiefood \#mouthfoods \#treatyoself \#huffposttaste \#spoonfeed \#feastagram \#yum \#hunarytwins

O

150 likes

Log in to like or comment.

Fig 1. Sample of Content Marketing: Storytelling.

Source: https://marketinginsidergroup.com/content-marketing/6-examples-genius-brand-storytellingsee (2019)

There are several things that must be considered when creating content in the form of storytelling, namely the topic of discussion of the storytelling, the target audience, the story structure, and also pictures or videos that support the contents of the story. This is according to research conducted by Harad $\mathrm{K}$. which says that content marketing is a belief to share opinions and knowledge which can be done through storytelling content marketing [5].

Content marketing can use the Frequently Asked Question (FAQ). FAQ is a list of questions and answers on a particular topic. The format is often used in articles, websites, email lists, and online forums where common questions tend to occur (see Figure 2). 


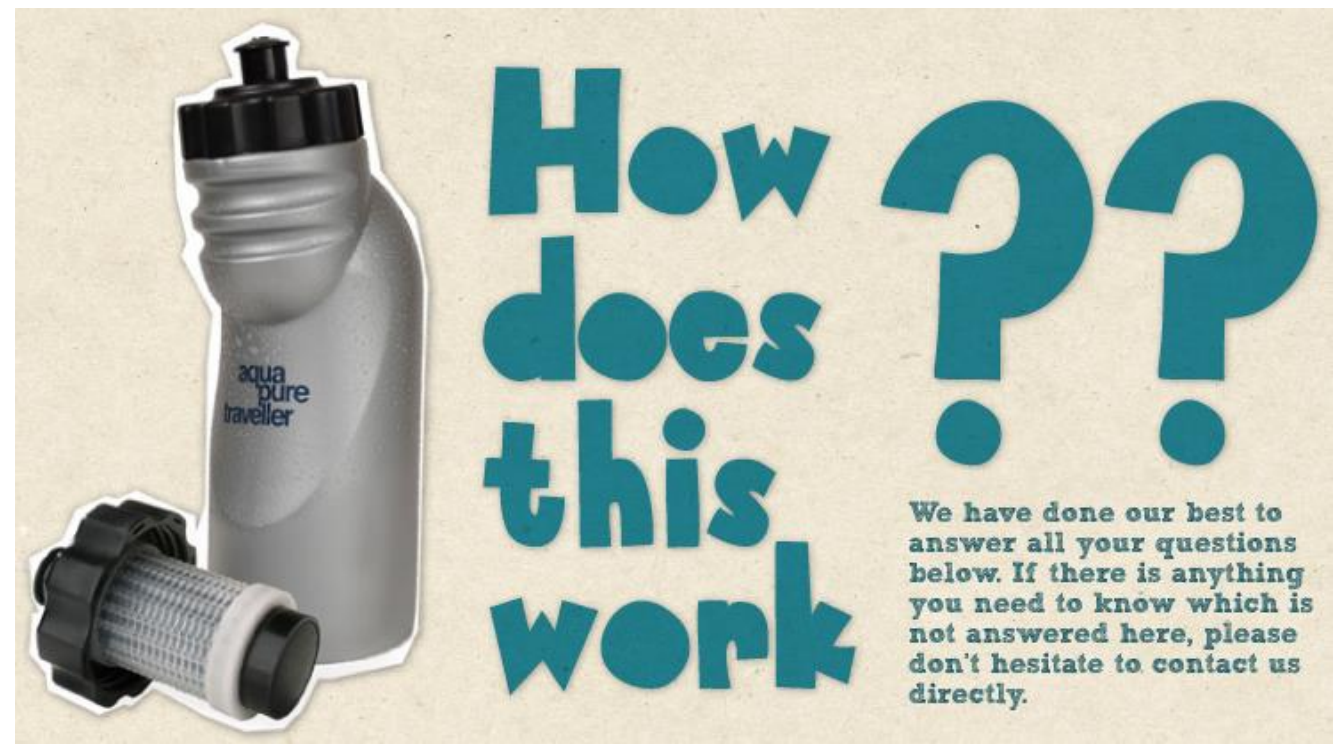

Fig 2. Sample of Content Marketing: TAQ.

Source: https://www.purehydration.com/about-pure-hydration/faqs/ (2019)

With the content in the form of frequently asked question (FAQ) in a website, it will be easier for consumers to ask something about the product and also the FAQ serves as a means for consumers to express their aspirations or complaints.

Content marketing can use media coverage. Media coverage is whatever the media decides to cover. You can assist their decision-making by providing a news story on behalf of a client, or by reporting a story you think is news worthy (Figure 3).

\section{WSJ Fortune Forbes govmoney reuters

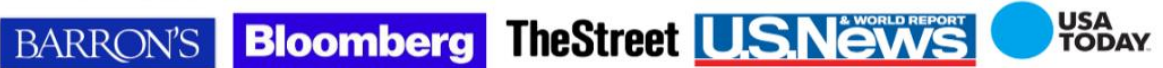 \\ - Leafly FORUM ${ }_{\text {Close deals }}^{\text {Growes. }}$ LAWEEKLYY Marijuana Business Daily.

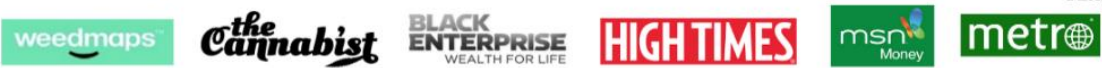

Fig 3. Sample of Content Marketing: Media Coverage. Source: https://www.viridianca.com/viridian-media-coverage/ (2019) 
With the content in the form of media coverage, consumers who see media coverage will increasingly believe in the products offered by a business because if a product has been covered by many media outlets, both national and international media, this indicates that the product has a good quality. Product information can be used in content marketing (Figure 4).

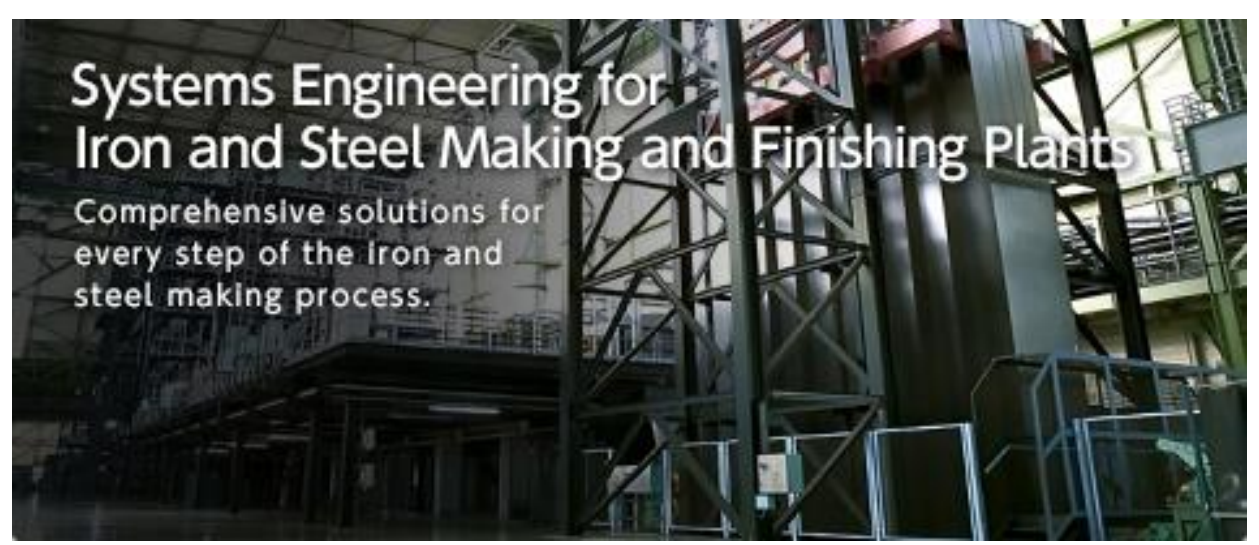

Fig 4. Sample of Content Marketing with product information. Source: https://www.nidec.com/en-NA/product/

With the content in the form of detailed product information, consumers will know more about a product and the advantages of said product that distinguishes it from other products.

Review or testimonials from customers will have a big impact for marketing product. An example can be seen in (Figure 5).

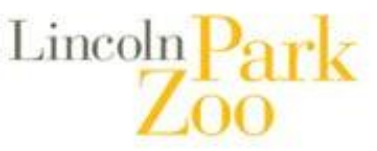

"We developed a great partnership with Orbit Media and their dedication to our website is evident in all aspects of the site. We appreciate their attention to detail and creative approach to bringing our new exhibit to life online."

PECGY MARTIN, Senior Director of Design and Communications, Lincoln Park Zoo

Figure 5. Sample of Content Marketing with testimonials.

Review or testimonials from customers will have a big impact, especially if the product review is given by public figures. By summarizing product reviews from customers in the form 
of stories, this will touch the heart of the audience and make them increasingly believe in the product of the brand.

The type of content used in Instagram is content in the form of photos and videos accompanied by captions. Each uploaded photo and video is accompanied by a different caption that is made as attractive as possible so that in addition to providing information on the uploaded images or photos and overcoming the consumers' curiosity about the products sold, it is also expected to influence customers to decide on the purchase of products.

From the explanation above, it is found that content marketing is very important to increase customer trust. Halvorson said content marketing is marketing technique [4]. Content marketing takes many forms such as storytelling, FAQ, media coverage, product information, and testimonials.

\section{Conclusion}

Attractive content marketing can help increase customer's trust in the product or service being offered through marketing a brand's content which can convey the values that are applied to the business and various information related to the product or service offered. This is from where the community will be aware of the existence of a brand, recognize character and value, and will put trust in the products or services offered by a business so that eventually the relationship between the brand and the consumer will be built.

\section{References}

[1] Ahmad, N. S., Musa, R., \& Harun, M. H. M. : The impact of social media content marketing (SMCM) towards brand health. Procedia Economics and Finance, 37, 331-336. (2016).

[2] Baltes, L. P. : Content marketing-the fundamental tool of digital marketing. Bulletin of the Transilvania University of Brasov. Economic Sciences. Series V, 8(2), 111 (2015).

[3] Grubor, A., \& Milovanov, o. : Content marketing: creating, maintaining and enhancing brand equity. $19^{\text {th }}$ Ebes Conference Istanbul Proceeding (2016).

[4] Halvorson, K., \& Rach, M. : Content strategy for the web. New Riders (2012).

[5] Harad, K. C. : Content marketing strategies to educate and entertain. Journal of Financial Planning, 26(3), 18-20 (2013).

[6] Holliman, G., \& Rowley, J. : Business to business digital content marketing: marketers' perceptions of best practice. Journal of research in interactive marketing, 8(4), 269-293 (2014).

[7] Limandono, J. A. : Pengaruh Content Marketing dan Event Marketing Terhadap Customer Engagement Dengan Sosial Media Marketing Sebagai Variabel Moderasi di Pakuwon City. Jurnal Strategi Pemasaran, 5(1), 11 (2018).

[8] Slater, S. F., \& Olson, E. M. : Marketing's contribution to the implementation of business strategy: An empirical analysis. Strategic Management Journal, 22(11), 1055-1067(2001).

[9] Soegoto, E. S. : Entrepreneurship Menjadi Pebisnis Ulung Edisi Revisi. Elex Media Komputindo (2014).

[10] Varadarajan, R. : Strategic marketing and marketing strategy: domain, definition, fundamental issues and foundational premises. Journal of the Academy of Marketing Science, 38(2), 119-140 . (2010).

[11] Opreana, A., \& Vinerean, S. : A new development in online marketing: Introducing digital inbound marketing. Expert Journal of Marketing, 3(1) (2015). 